\title{
触 New Disease Reports \\ Colletotrichum brevisporum is associated with
anthracnose of red bell pepper fruit in Trinidad
}

R.T. Villafana, A.C. Ramdass and S.N. Rampersad*

Biochemistry Research Laboratory, Department of Life Sciences, Faculty of Science and Technology, The University of the West Indies, St. Augustine, Trinidad and Tobago

*E-mail: sephra.rampersad@sta.uwi.edu

Received: 13 Mar 2019. Published: 19 Mar 2019. Keywords: Capsicum annuum, fruit rot

Bell pepper (Capsicum annuum) production in Trinidad is year-round and covers approximately 116 acres with an estimated annual yield of 1,600 tonnes. Colletotrichum truncatum is the predominant fungal pathogen causing anthracnose of pepper fruit and C. gloeosporioides sensu lato is secondary due to its sensitivity to methyl benzimidazole carbamate fungicides which are now routinely used in Trinidad (Ramdial \& Rampersad, 2015). For the last ten years, shifts in the Colletotrichum population in bell pepper fields have been monitored. From September 2012 to 2017, red bell pepper fruit with sunken, brown lesions were collected from fields located in the main growing areas (Figs. 1-2; Table 1). Symptomatic fruits (Fig. 3) were surface sterilised and a $5-\mathrm{mm}^{3}$ block of tissue from each lesion edge was placed onto potato dextrose agar (PDA) amended with $50 \mathrm{mg} / \mathrm{l}$ each of streptomycin sulphate, tetracycline and chloramphenicol, and incubated for seven days at $25^{\circ} \mathrm{C}$ under a $12-\mathrm{hr}$ photoperiod. Colonies were orange in aerial view and cream to pale brown in reverse. Conidia were unicellular, hyaline, aseptate, cylindrical with rounded ends and measured 12-14 $\mu \mathrm{m} \times 3-4 \mu \mathrm{m} ; n=15$ (Fig. 4).

Pathogen identity was determined through multi-locus sequence comparisons of the internally transcribed spacer (ITS1-5.8S-ITS2) (GenBank Accession Nos. MG827234-5), actin (ACT) (GenBank Accession Nos. MG870320-1), and beta-tubulin ( $\beta$-TUB) (GenBank Accession Nos. MG839690-1) gene regions according to Damm et al. (2019). Sequence similarities of the Trinidadian bell pepper isolates were highest for $C$. brevisporum with $99 \%$ identity to KX756146 for the ITS sequences (100\% coverage; 0.0 E-value), $100 \%$ identity to KY319108 for the $\beta$-TUB sequences and $100 \%$ identity to KX878886 for the ACT sequences (both $100 \%$ coverage; 0.0 E-value). Colletotrichum brevisporum forms a sister group to $C$. cliviae (Noireung et al., 2012).

Pathogenicity tests were repeated with four isolates in duplicate using the wounded/non-wounded inoculation method on healthy red and green fruits. For wound inoculation, the surface of each fruit (cv. Aristotle) was punctured at two sites using a sterile needle to a depth of approximately 2 $\mathrm{mm}$. Mycelial blocks $\left(5 \mathrm{~mm}^{3}\right)$ from the margin of actively growing colonies were placed over the wounded and non-wounded sites. PDA blocks with no fungal growth served as the negative control. Inoculated fruits were incubated in a humid chamber for seven days at $25^{\circ} \mathrm{C}$ in the dark. Only red fruits inoculated at wounded sites developed lesions similar to those observed in the field and which are distinct from those caused by $C$. truncatum. Green fruits and control fruits remained healthy. This approach, though artificial, was used because of the difficulty in conducting field pathogenicity tests and sparse sporulation in vitro prevented effective spray or droplet inoculation under laboratory conditions. Koch's postulates were fulfilled with the re-isolation and identification of $C$. brevisporum from symptomatic fruits using DNA sequence comparisons.

Colletotrichum brevisporum was reported to cause anthracnose disease of different Capsicum species in Brazil (de Almeida et al., 2017; Mongkolporn \& Taylor, 2018) and in China (Liu et al., 2016). This is the first report of $C$. brevisporum infecting red bell pepper fruit in Trinidad. Fungicide sensitivity of this Colletotrichum species must be assessed since this data will impact on disease management strategies.

\section{Acknowledgements}

This research was funded by a Campus Research and Publications Grant (\#CRP.3.MAR16.12) of The University of the West Indies, St. Augustine, Trinidad and Tobago.

\section{References}

Damm U, Sato T, Alizadeh A, Groenewald JZ, Crous PW, 2019. The Colletotrichum dracaenophilum, C. magnum and C. orchidearum species complexes. Studies in Mycology 92, 1-46.

http://dx.doi.org/10.1016/j.simyco.2018.04.001

de Almeida LB, Matos KS, Assis LAG, Hanada RE, da Silva GF, 2017. First report of anthracnose of Capsicum chinense in Brazil caused by Colletotrichum brevisporum. Plant Disease, 1035. http://dx.doi.org/10.1094/PDIS-01-17-0099-PDN

Liu F, Tang G, Zheng X, Li Y, Sun X, Qi X, Zhou Y, Xu J, Chen H, Chang X, Zhang S, Gong G, 2016. Molecular and phenotypic characterization of Colletotrichum species associated with anthracnose disease in peppers from Sichuan Province, China. Scientific Reports , 32761 . http://dx.doi.org/10.1038/srep32761

Mongkolporn O, Taylor PWJ, 2018. Chili anthracnose: Colletotrichum taxonomy and pathogenicity. Plant Pathology 67, 1255-1263. http://dx.doi.org/10.1111/ppa.12850

Noireung P, Phoulivong S, Liu F, Cai L, Mckenzie EH, Chukeatirote E, Jones EBG, Bahkali AH, Hyde KD, 2012. Novel species of Colletotrichum revealed by morphology and molecular analysis. Cryptogamie Mycologie 33, 347-362. http://dx.doi.org/10.7872/crym.v33.iss3.2012.347

Ramdial H, Rampersad SN, 2015. Characterization of Colletotrichum spp. causing anthracnose of bell pepper (Capsicum аппиит L.) in Trinidad. Phytoparasitica 43, 37-49. http://dx.doi.org/10.1007/s12600-014-0428-z

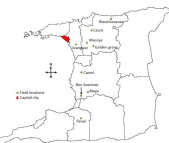

Figure 1

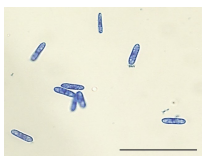

Figure 4

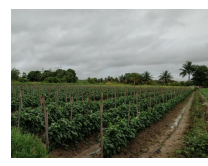

Figure 2

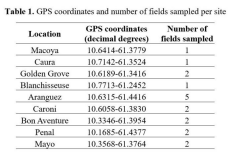

Figure 3

To cite this report: Villafana RT, Ramdass AC, Rampersad SN, 2019. Colletotrichum brevisporum is associated with anthracnose of red bell pepper fruit in Trinidad. New Disease Reports 39, 11. http://dx.doi.org/10.5197/j.2044-0588.2019.039.011

(c) 2019 The Authors

This report was published on-line at www.ndrs.org.uk where high quality versions of the figures can be found. 